\title{
KINERJA REKSA DANA SYARIAH DI PASAR MODAL INDONESIA
}

\author{
Nana Sepdiana \\ Sekolah Tinggi Ilmu Ekonomi (STIE) Syariah Bengkalis \\ Email: nanasepdiana1989@gmail.com
}

\begin{abstract}
ABSTRAK
Tujuan dari penelitian ini adalah untuk menganalisis kinerja reksadana syariah yang meliputi saham, pendapatan tetap, campuran, dan pasar uang. Jenis penelitian yang dilakukan adalah penelitian deskriptif kuantitatif. Metode pengumpulan data dalam penelitian ini adalah teknik dokumentasi dengan data sekunder yaitu melalui situs resmi bareksa.com. Pengukuran kinerja reksadana syariah dalam penelitan ini menggunakan satu metode saja yaitu metode sharpe. Berdasarkan perhitungan Sharpe dapat disimpulkan bahwa kinerja tertinggi di antara reksa dana syariah yang meliputi saham, pendapatan tetap, campuran dan pasar uang pada tahun 2015, 2016, dan 2017 adalah reksa dana saham syariah.
\end{abstract}

Kata Kunci: Kinerja, Reksa Dana Syariah

\section{PENDAHULUAN}

Investasi merupakan cara masyarakat dalam menambah harta kekayaan mereka. Ada banyak bentuk investasi seperti investasi uang dalam bentuk tabungan, investasi emas, serta investasi efek. Pemerintah telah memberikan wadah bagi para calon investor yang mau berinvestasi. Seperti jika ingin investasi uang dapat dilaksanakan di bank. Jika ingin investasi emas dapat dilakukan di pegadaian serta jika ingin investasi efek dapat dilaksanakan di pasar modal.

Raudhah dkk (2018), menjelaskan bahwa pasar modal memberikan berbagai manfaat bagi perekonomian Indonesia, pertama pasar modal menyediakan pertemuan antara debitur dan kreditur. Dana yang diperoleh debitur dapat digunakan untuk menambahkan modal bagi usahanya, ekspansi dan pengembangan usahanya. Penambahan dana yang disediakan oleh pasar modal akan meningkatkan kinerja perusahaan. Kinerja perusahaan yang meningkat akan memberikan kontribusi pajak yang tinggi bagi negara. Pajak yang tinggi dapat digunakan untuk membangun negara sehingga masyarakat luas dapat menikmati hasil pemerataan pendapatan.

Sarana yang ditawarkan investasi pasar modal meliputi saham, obligasi, dan reksadana. Investor yang membeli surat berharga akan mendapatkan tingkat pengembalian dan deviden. Deviden yang diperoleh akan dipotong untuk pajak negara. Pajak yang dipotong akan meningkatkan pendapatan negara.

Salah satu produk investasi syariah yang ditawarkan di pasar modal yaitu reksadana syariah. Hasbi (2010), menjelaskan berbagai macam jenis reksadana syariah muncul, diantaranya yaitu reksadana syariah saham, reksadana pendapatan tetap, reksadana syariah campuran, dan reksadana syariah terproteksi. Reksadana syariah sangat diminati oleh para investor. Investor sangat berminat dengan salah satu jenis investasi syariah ini dikarenakan sesuai dengan prinsip Al-Quran dan 
Hadist. Reksadana Syariah harus terhindar dari riba, masyir, gharar. Riba dapat diartikan sebagai pengambilan tambahan keuntungan. Prinsip masyir dapat diartikan sebagai spekulasi, sedangkan gharar di definisikan sebagai ketidakjelasan.

Fatwa Dewan Syariah Nasional (DSN) MUI Nomor 20/DSN MUI/IV/2001 mendefinisikan reksa dana syariah sebagai reksa dana yang beroperasi menurut ketentuan dan prinsip syariah Islam, baik dalam bentuk akad antara pemodal sebagai pemilik harta (Shahib al-mal/rabb al-mal) dengan manajer investasi sebagai wakil Shahib al-mal, maupun antara manajer investasi sebagai wakil Shahib al-mal dengan pengguna investasi.

Reksa Dana merupakan instrumen investasi yang dikelola oleh Manajer Investasi sehingga investor memiliki informasi produk Reksa Dana yang valid dari pihak Manajer Investasi tersebut. Berinvestasi melalui Reksa Dana juga lebih murah dibandingkan instrumen lain karena Manajer Investasi memiliki tugas untuk mengumpulkan dan mengelola dana dari para investor untuk dialokasikan ke pasar modal. Dana yang terkumpul dari beberapa investor tentunya lebih besar daripada dana hanya dari satu orang investor saja sehingga keuntungan yang diharapkan juga lebih besar. Manajer Investasi juga akan melalukan diversifikasi untuk meminimalisir risiko.

Karakteristik Reksa Dana syariah memiliki dewan pengawas syariah. Dewan pengawas syariah ini bertugas mengawasi fungsi-fungsi yang dijalankan oleh Reksa Dana syariah, yang meliputi pengecekan kehalalaan dan promosi. Dewan pengawas syariah juga memberikan nasehat dan pertimbangan pemanfaatan dana sosial serta edukasi.

Fatra (2014), menjelaskan bahwa di dalam Reksa Dana syariah terdapat proses screening yang merupakan proses penyaringan sekuritas yang sesuai dengan syariat dan juga proses cleansing yaitu proses penghapusan sekuritas yang tidak sesuai syariat sehingga keuntungan yang dihasilkan sekuritas tersebut harus dikeluarkan dan diamalkan.

Pertumbuhan Reksa Dana syariah cukup pesat, hal ini ditandai pertumbuhan Nilai Aktiva Bersih (NAB) pada tahun 2017 sebesar 38,25 persen. Lebih besar dibanding Reksa Dana konvensional yang menunjukkan Nilai Aktiva Bersih (NAB) sebesar 25,45 persen. Nilai Aktiva Bersih (NAB) pada Desember 2016 tercatat hanya sebesar Rp 14,91 triliun meningkat menjadi Rp 20,62 triliun pada tahun 2017. Berikut ini dapat dilihat pada Gambar 1 perkembanganya:

\section{Gambar 1}

\section{Perkembangan Reksa Dana Syariah}

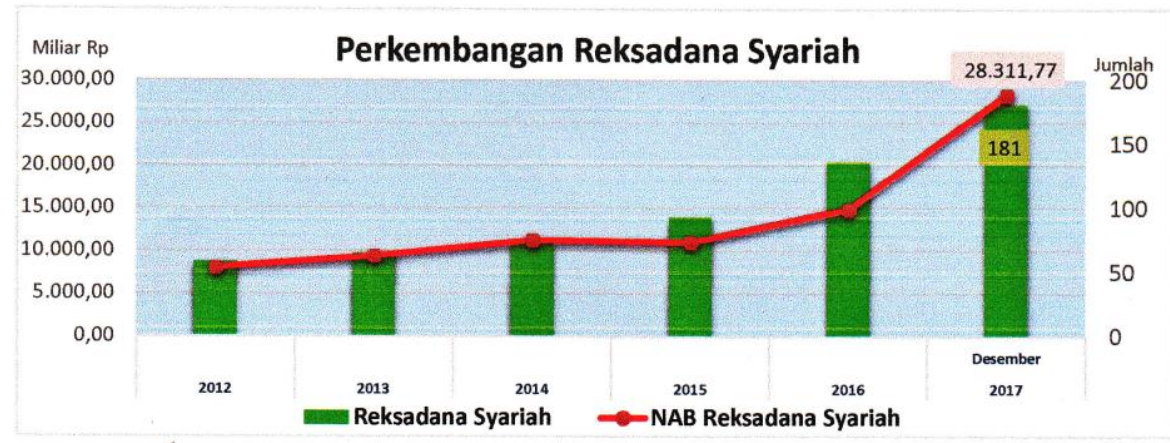


Perkembangan Reksa Dana syariah yang pesat ini diikuti dengan jumlah produk Reksa Dana syariah dari 136 produk (Desember 2016) menjadi 160 produk per Agustus. Jumlah produk Reksa Dana konvensional per Agustus mencapai 1469 produk. Pangsa pasar Reksa Dana syariah hanya 5 persen dibanding total Reksa Dana secara nasional (www.ojk.com).

Kinerja Reksa Dana syariah cukup bagus, hal ini ditunjukkan dengan imbal hasil Reksa Dana saham syariah sebesar 1,44 persen. Kinerja Reksa Dana yang meningkat hal ini disebabkan oleh infrastruktur dan komoditas yang naik. Reksa Dana diperkirakan akan memberikan imbal hasil yang meningkat. Reksa Dana syariah saham imbal hasilnya sebesar 10 persen, syariah campuran 8 persen, pendapatan syariah 7 persen, pasar uang syariah 4 persen. Kinerja ini ditompang oleh saham yang bergerak di sektor infrastruktur dan aneka industri (Hendrayana 2017).

Adapun penelitian terdahulu yang berkaitan dengan reksadana syariah seperti Wiksuana (2008) dan Suryatini (2007) menyatakan kinerja reksa dana syariah pendapatan tetap lebih baik dari kinerja pasarnya, begitu pula dengan penelitian Hakim \& Rashidian (2002), Haruman \& Hasbi (2005) bahwa Reksa Dana syariah saham berkinerja lebih baik dari indeks pasarnya.

Namun berbeda dengan hasil penelitian dari Werner R Murhadi (2009) yang menunjukkan bahwa dalam periode 2008-2009 yang ditandai dengan penurunan IHSG begitu tajam, ternyata telah membuat banyak reksadana yang mengalami penurunan kinerja signifikan.

Dengan adanya gap research tersebut, peneliti tertarik untuk melakukan penelitian berkaitan tentang kinerja Reksadana syariah di pasar modal. Dalam mengukur kinerja reksadana tidak hanya dilihat dari return yang akan didapatkan, melainkan juga harus memperhitungkan besar resiko yang akan diterima. Terdapat beberapa metode yang termasuk risk adjusted return, yaitu metode sharpe, metode teynor, metode jensen.

Dalam penelitian ini peneliti menggunakan metode sharpe. Metode sharpe mendasarkan perhitungan pada konsep garis pasar modal sebagai patok duga, yaitu dengan cara membagi premi resiko portofolio dengan standart deviasinya (resiko total), sehingga bisa mengukur premi resiko untuk setiap unit resiko pada portofolio tersebut (Tanderlilin 2010). Kinerja portofolio dapat diukur hanya dengan satu metode, Metode Indeks Sharpe ini sudah mengakomodir kebutuhan calon investor karena telah memperhitungkan resiko secara keseluruhan (Rahma 2016).

Metode Sharpe merupakan standart pengukuran kinerja reksadana secara Internasional yang dikembangkan oleh William F. Sharpe pada tahun 1966 yang telah teruji. Secara umum model pengukuran kinerja metode Sharpe dapat diterapkan untuk semua jenis reksadana sehingga pengguna metode ini dapat menggambarkan kemampuan manajer investasi dalam mengolah reksadana dari setiap unit resiko yang diambil. Selain itu, disebutkan dalam situs www.bareksa.com bahwa metode Sharpe ini merupakan salah satu metode yang paling banyak digunakan di Indonesia. Dalam ajang penghargaan reksa dana terbaik 2013, penggunaan metode Sharpe salah satunya merupakan kriteria dalam menentukan Reksadana terbaik tersebut (www.bareksa.com). 


\section{LANDASAN TEORI}

\section{Pengertian Reksa Dana Syariah}

Menurut Undang-Undang Nomor 8 Tahun 1995 tentang Pasar Modal menyebutkan bahwa Reksa Dana adalah wadah yang dipergunakan untuk menghimpun dana dari masyarakat pemodal untuk selanjutnya diinvestasikan dalam portofolio efek oleh manajer investasi. Definisi manajer investasi menurut Undang-Undang ini adalah pihak yang kegiatannya mengelola portofolio efek untuk para nasabah atau mengelola portofolio investasi kolektif untuk sekelompok nasabah, kecuali perusahaan asuransi, dana pensiun, dan bank yang melakukan sendiri kegiatan usahanya berdasarkan peraturan perundang-undangan yang berlaku.

Berdasarkan Fatwa Dewan Syariah Nasional No. 20/DSN-MUI/IV/2000 dalam Himpunan Fatwa Dewan Syariah Nasional (2003), Reksa Dana Syariah adalah Reksa Dana yang beroperasi menurut ketentuan dan prinsip syariah Islam, baik dalam bentuk akad kerjasama antara pemodal sebagai pemilik harta (shahibul maal) dengan Manajer Investasi sebagai wakil pemilik harta dengan pengguna investasi.

Menurut Sutedi (2011), reksa dana syariah merupakan reksa dana yang mengalokasikan seluruh dana atau portofolio ke dalam instrumen syariah, seperti saham yang tergabung dalam Jakarta Islamic Index (JII), obligasi syariah dan berbagai instrumen keuangan syariah lainnya.

\section{Tujuan Reksa Dana Syariah}

Salah satu tujuan dari Reksa Dana Syariah adalah memenuhi kebutuhan kelompok investor yang ingin memperoleh pendapatan investasi dari sumber dan cara yang bersih dan dapat dipertanggungjawabkan secara religius, serta sejalan dengan prinsip-prinsip syariah. Dengan demikian, reksa dana syariah adalah suatu wadah yang digunakan oleh masyarakat untuk berinvestasi secara kolektif, di mana pengelolaan dan kebijakan investasinya mengacu pada syariat Islam.

Diah dkk (2018), menyebutkan bahwa reksadana syariah merupakan sarana bagi umat Islam untuk ikut berpartisipasi dalam pembangunan nasional melalui investasi yang sesuai dengan syariat islam.

\section{Ciri-ciri Reksa Dana Syariah}

Adapun ciri-ciri dari Reksa Dana syariah menurut Firdaus et.al (2005) sebagai berikut:

1. Mempunyai Dewan Syariah yang bertugas memberikan arahan kegiatan manajer investasi agar senantiasa sesuai dengan syariah Islam.

2. Hubungan antara investor dan perusahaan didasarkan pada sistem mudharabah, dimana satu pihak menyediakan 100 persen modal (investor), sedangkan satu pihak yang lain sebagai pengelola (manajer investasi).

3. Kegiatan usaha atau investasinya diarahkan pada hal-hal yang tidak bertentangan dengan syariah Islam. 


\section{METODE PENELITIAN}

Penelitian ini merupakan penelitian studi kasus. Jenis penelitian yang dilakukan yaitu penelitian deskriptif kuantitatif. Subjek penelitian dalam penelitian ini adalah seluruh jenis Reksa Dana syariah yang terdaftar di Bursa Efek Indonesia pada periode 2015-2017 setidaknya ada 10 jenis Reksa Dana Syariah, dan hanya ada 4 jenis Reksa Dana Syariah yang dianalisis dalam penelitian ini yaitu:

1. Reksa Dana Syariah Saham

2. Reksa Dana Syariah Pendapatan Tetap

3. Reksa Dana Syariah Campuran

4. Reksa Dana Syariah Pasar Uang

Pemilihan ke empat jenis Reksa Dana Syariah tersebut berdasarkan kriteria yang diambil sebagai berikut:

1. Sampel yang digunakan merupakan Reksa Dana Syariah yang aktif beroperasi di pasar modal Indonesia pada tahun 2015-2017.

2. Sampel yang digunakan merupakan Reksa Dana Syariah yang memiliki kinerja terbaik pada tahun 2015-2017 dilihat dari NAB (Nilai Aktiva Bersih).

Penelitian ini hanya menggunakan data sekunder. Metode pengumpulan data dalam penelitian ini adalah teknik dokumentasi. Teknik dokumentasi dilakukan dengan cara mendownload atau mengcopy data yang ada pada jasa keuangan, infovesta, bareksa dan badan pengawas pasar modal. Analisis data dilakukan dengan tahapan sebagai berikut:

1. Tingkat Pengembalian Realisasi Reksa Dana

Menurut Jogiyanto (2009), Tingkat pengembalian dapat diukur dengan menggunakan rumus sebagai berikut.

Keterangan:

$$
\mathrm{R}_{1}=\frac{N A B_{t-} N A B_{t-1}}{N A B_{t-1}}
$$

$\mathrm{Ri} \quad=$ Tingkat pengembalian Investasi

$\mathrm{NABt}=\mathrm{NAB}$ bulan sekarang

NABt-1 $=$ NAB bulan lalu

2. Menentukan Tingkat Pengembalian ekspektasi Reksa Dana

Keterangan:

$$
\mathrm{E}\left(\mathrm{R}_{1}\right)=\frac{\sum_{t=1}^{n} R_{i}}{n-1}
$$

$\mathrm{E}(\mathrm{Ri}) \quad=$ Tingkat pengembalian ekspektasi Reksa Dana $\mathrm{i}$

Ri $\quad=$ Tingkat pengembalian Realisasi dari Reksa Dana i

$\mathrm{n} \quad=$ Jumlah periode selama transaksi

3. Menentukan Tingkat Risiko Reksa Dana

a. Menentukan variance Reksa Dana

$$
\operatorname{Var}(\mathrm{Ri})=\frac{\sum_{t=1}^{n}\left(\left(R i-E\left(R_{1}\right)\right)^{2}\right.}{n-1}
$$

Keterangan:

$$
\begin{array}{ll}
\operatorname{Var}(\mathrm{Ri}) & =\text { Variance dari pengembalian investasi } \\
\mathrm{E}(\mathrm{Ri}) & =\text { Tingkat pengembalian ekspektasi Reksa Dana i } \\
\mathrm{Ri} & =\text { Tingkat pengembalian Realisasi dari Reksa Dana i } \\
\mathrm{n} & =\text { Jumlah periode selama transaksi }
\end{array}
$$


b. Menentukan standar deviasi Reksa Dana

$$
\sigma \mathrm{i}=\sqrt{\operatorname{var}\left(E\left(R_{1}\right)\right.}
$$

Keterangan:

бi $\quad=$ Standar deviasi Reksa Dana

Var $(\mathrm{Ri}) \quad=$ Variance dari pengembalian investasi

c. Menentukan covariance Reksa Dana

$$
\operatorname{COV}(\mathrm{A}, \mathrm{B})=\sum_{t=1}^{n}\left(P_{i}\right)\left(\left(R_{A 1}-E\left(R_{i}\right)\right)\left(R_{B i}-E\left(R_{B}\right)\right)\right.
$$

Keterangan:

$\mathrm{Pi}=$ probabilitas diraihnya tingkat pengembalian

$\mathrm{RAi}=$ tingkat pengembalian realisasi dari investasi pada saham A pada keadaan i

$\mathrm{RBi}=$ tingkat pengembalian realisasi dari investasi pada saham B pada keadaan $\mathrm{i}$

$\mathrm{E}(\mathrm{RA})=$ tingkat pengembalian ekspektasi dari investasi saham A

$\mathrm{E}(\mathrm{RB})=$ tingkat pengembalian ekspektasi dari investasi saham $\mathrm{B}$

4. Mengukur Kinerja Reksa Dana Menggunakan Metode Sharpe

Keterangan:

$$
S p_{i}=\frac{R p_{i}-R_{f}}{S D p_{i}}
$$

Spi $\quad=$ Indeks Sharpe portofolio $\mathrm{i}$

Rpi = rerata imbal hasil portofolio $\mathrm{i}$

$\mathrm{R}_{\mathrm{f}} \quad=$ rerata atas bunga investasi bebas risiko

SDpi = standar deviasi dari imbal hasil portofolio

\section{HASIL DAN PEMBAHASAN}

Penelitian ini dilakukan untuk mengetahui tingkat kinerja dari Reksa Dana Syariah Pendapatan Tetap, Reksa Dana Syariah Saham, Reksa Dana Syariah Pasar Uang, serta Reksa Dana Syariah Campuran yang diperdagangkan pada Pasar Modal Indonesia. Analisis kinerja Reksa Dana Syariah dalam penelitian ini, sesuai dengan metode analisis penelitian ini dengan menggunakan tingkat pengembalian, risiko, dan alat ukur kinerja berbasis risiko terhadap berbagai macam bentuk reksadana. Kemudian kinerja masing - masing menggunakan indeks Sharpe.

\section{Menentukan Tingkat Pengembalian}

Analisis kinerja Reksa Dana Syariah yang pertama yaitu menggunakan tingkat pengembalian bulanan, yang dicari dengan menentukan tingkat pengembalian tertinggi, terendah, dan rata-rata (ekspektasi) bulan JanuariDesember pada 2015, 2016 dan 2017.

Hasil perhitungan tingkat pengembalian bulanan Reksa Dana syariah saham pada 2015, 2016 dan 2017 dapat dilihat pada Tabel 1. 


\section{Tabel 1}

Hasil Tingkat Pengembalian Realisasi dan Ekspektasi Reksa Dana Syariah Saham Bulanan Pada Tahun 2015-2017

\begin{tabular}{|c|l|r|r|}
\hline Tahun & \multicolumn{1}{|c|}{ Keterangan } & \multicolumn{1}{c|}{$\mathbf{R i} \%$} & \multicolumn{1}{c|}{ E(Ri) } \\
\hline \multirow{3}{*}{2015} & Tertinggi (Oktober) & 11,3425 & 0,43625 \\
\cline { 2 - 4 } & Terendah (Agustus) & $-10,51$ & $-0,40423$ \\
\cline { 2 - 4 } & Rata-rata & $-1,38149$ & $-0,05313$ \\
\hline \multirow{2}{*}{2016} & Tertinggi (Juli) & 8,691667 & 0,334295 \\
\cline { 2 - 4 } & Terendah (November) & $-6,37333$ & $-0,24513$ \\
\cline { 2 - 4 } & Rata-rata & 1,453528 & 0,055905 \\
\hline \multirow{2}{*}{2017} & Tertinggi (Januari) & 3,790833 & 0,125801 \\
\cline { 2 - 4 } & Terendah (September) & $-2,72$ & $-0,10462$ \\
\cline { 2 - 4 } & Rata-rata & 0,496461 & 0,019095 \\
\hline
\end{tabular}

Sumber: data diolah

Berdasarkan Tabel 1 diatas, pada tahun 2015, menunjukkan bahwa tingkat pengembalian realisasi tertinggi dan terendah memiliki nilai yang lebih tinggi daripada tingkat pengembalian ekspetasi pada Reksa Dana syariah saham. Pada tahun 2016 dan 2017 menunjukkan bahwa tingkat pengembalian realisasi lebih tinggi dari tingkat pengembalian ekspetasi. Hal ini menunjukkan kinerja yang terbaik Reksa Dana Saham Syariah pada tahun 2016 meskipun tingkat pengembalian pada tahun 2015 lebih besar dibandingkan tahun 2016 tetapi dilihat dari nilai rata-rata tingkat pengembalian masih lebih besar tahun 2016.

Analisis tingkat pengembalian kedua dilakukan pada Reksa Dana Syariah Pendapatan Tetap. Hasil perhitungan tingkat pengembalian bulanan tertinggi, terendah, dan rata-rata pada Reksa Dana pendapatan tetap pada Januari-Desember 2015, 2016 dan 2017 secara lengkap pada Tabel 2.

\section{Tabel 2}

Hasil Tingkat Pengembalian Realisasi dan Ekspektasi Reksa Dana Syariah Pendapatan Tetap Bulanan pada 2015-2017

\begin{tabular}{|c|l|r|r|}
\hline Tahun & \multicolumn{1}{|c|}{ Keterangan } & \multicolumn{1}{|c|}{ Ri\% } & \multicolumn{1}{c|}{$\mathbf{E}(\mathbf{R i})$} \\
\hline \multirow{3}{*}{2015} & Tertinggi (Oktober) & 1,83 & 0,0703846 \\
\cline { 2 - 4 } & Terendah (Agustus) & $-0,055$ & $-0,0021154$ \\
\cline { 2 - 4 } & Rata-rata & 0,579167 & 0,0222756 \\
\hline \multirow{2}{*}{2016} & Tertinggi (Maret) & 1,665 & 0,064038 \\
\cline { 2 - 4 } & Terendah (Maret) & $-0,355$ & $-0,01365$ \\
\cline { 2 - 4 } & Rata-rata & 0,744583 & 0,028093 \\
\hline \multirow{2}{*}{2017} & Tertinggi (September) & 1,635 & 0,062885 \\
\cline { 2 - 4 } & Terendah (September) & $-0,075$ & $-0,00288$ \\
\cline { 2 - 4 } & Rata-rata & 0,566667 & 0,021795 \\
\hline
\end{tabular}

Sumber: data diolah

Berdasarkan Tabel 2 di atas tingkat pengembalian terbesar yang diberikan kepada investor ada pada tahun 2015 bulan Januari yaitu sebesar 1,83. Nilai Ri selanjutnya ada di tahun 2016 bulan Maret yaitu tercatat sebesar 1,665. Pada tahun 2017 nilai Ri masih menunjukkan nilai positif, akan tetapi mengalami penurunan sebesar 0,03 menjadi 1,635. Nilai Ri terendah ada di tahun 2016 pada bulan November sebesar $-0,355$. 
Kinerja Reksa Dana Syariah Pendapatan Tetap terbaik ada di tahun 2016 meskipun secara nilai tingkat pengembalian selalu mengalami penurunan akan tetapi rata-rata pada tahun 2016 lebih tinggi apabila dibanding lainnya, selain itu juga nilai pengembalian ekspetasi masih lebih kecil dibanding tingkat pengembalian realisasinya.

Analisis tingkat pengembalian ketiga dilakukan pada Reksa Dana Syariah Campuran. Hasil perhitungan tingkat pengembalian bulanan tertinggi, terendah, dan rata-rata pada Reksa Dana Pendapatan Tetap pada Januari-Desember 2015, 2016 dan 2017 secara lengkap pada Tabel 3.

Tabel 3

Hasil Tingkat Pengembalian Realisasi dan Ekspektasi

Reksa Dana Syariah Campuran Bulanan pada 2015-2017

\begin{tabular}{|l|l|l|l|}
\hline \multicolumn{1}{|c|}{ Tahun } & \multicolumn{1}{|c|}{ Keterangan } & \multicolumn{1}{c|}{ Ri\% } & \multicolumn{1}{c|}{ E(Ri) } \\
\hline \multirow{3}{*}{2015} & Tertinggi (Oktober) & 8,744286 & 0,336319 \\
\cline { 2 - 4 } & Terendah (Agustus) & $-7,06714$ & $-0,2718$ \\
\cline { 2 - 4 } & Rata-rata & $-0,56869$ & $-0,02187$ \\
\hline \multirow{2}{*}{2016} & Tertinggi (Juli) & 6,795714 & 0,261374 \\
\cline { 2 - 4 } & Terendah (November) & $-5,36286$ & $-0,20626$ \\
\cline { 2 - 4 } & Rata-rata & 1,158929 & 0,044574 \\
\cline { 2 - 4 } & Tertinggi (Januari) & 2,687143 & 0,103352 \\
\cline { 2 - 4 } & Terendah (September) & $-0,96714$ & $-0,0372$ \\
\cline { 2 - 4 } & Rata-rata & 0,524524 & 0,020174 \\
\hline
\end{tabular}

Sumber: data diolah

Berdasarkan Tabel 3 di atas, kinerja Reksa Dana Syariah Campuran terbaik ada di tahun 2016 dimana nilai tingkat pengembalian realisasi sebesar 6,795714 lebih besar dibandingkan nilai tingkat pengembalian ekspetasi yang hanya sebesar 0,261374 . Nilai tingkat rata-rata pengembalian realisasi pada tahun 2016 sebesar 1,158929 lebih besar dibandingkan tahun sebelum dan sesudahnya.

Nilai Ri realisasi Reksa Dana Syariah Pasar Uang setiap tahunnya mengalami penurunan tingkat pengembalian disertai menurunnya nilai rata-rata pengembalian. Kinerja terbaik Reksa Dana Syariah Pasar Uang terbaik pada tahun 2015 dimana tingkat pengembalian terbesar dan nilai tingkat pengembalian ekspetasi lebih kecil dibandingkan tingkat pengembalian realisasinya.

Maka dapat dilihat pada Tabel 4 yang menunjukkan kinerja berbagai jenis Reksa Dana Syariah seperti Reksa Dana Syariah Saham, Reksa Dana Syariah Pendapatan Tetap, Reksa Dana Syariah Campuran, Reksa Dana syariah Pasar Uang.

Tabel 4

Tingkat Pengembalian Rata-Rata Tahunan Reksa Dana Syariah Pada 2015 - 2017

\begin{tabular}{|c|r|r|r|r|}
\hline Tahun & $\begin{array}{c}\text { Reksa Dana } \\
\text { Syariah Saham }\end{array}$ & $\begin{array}{c}\text { Reksa Dana } \\
\text { Syariah } \\
\text { Pendapatan tetap }\end{array}$ & $\begin{array}{c}\text { Reksa Dana } \\
\text { Syariah } \\
\text { Campuran }\end{array}$ & $\begin{array}{c}\text { Reksa Dana } \\
\text { Syariah } \\
\text { Pasar uang }\end{array}$ \\
\hline 2015 & $-1,38149$ & 0,579167 & $-0,56869$ & 0,4895833 \\
\hline 2016 & 1,453528 & 0,744583 & 1,158929 & 0,472083 \\
\hline
\end{tabular}




\begin{tabular}{|l|r|r|r|r|}
\hline 2017 & 0,496461 & 0,566667 & 0,524524 & 0,4979167 \\
\hline
\end{tabular}

Sumber: data diolah

Pada Tabel 4. Dapat disimpulkan bahwa jenis Reksa Dana Syariah yang memberikan kontribusi terbesar kepada investor yaitu Reksa Dana syariah saham pada tahun 2016 sebesar 1,453528. Tingkat pengembalian rata-rata terbesar selanjutnya yaitu Reksa Dana syariah campuran sebesar 1,158929. Tingkat pengembalian rata-rata ketiga yaitu Reksa Dana syariah pendapatan tetap, dan Reksa Dana yang menduduki peringkat paling akhir atau memiliki nilai rata-rata pengembalian realisasi paling kecil yaitu Reksa Dana pasar uang. Jadi, Reksa Dana yang memberikan tingkat pengembalian rata-rata tertinggi adalah Reksa Dana Saham.

\section{Pengukuran Risiko}

Alat analisis kinerja Reksa Dana Syariah kedua adalah risiko, yang diukur dengan deviasi standar atas tingkat pengembalian bulanan. Standar deviasi dihitung setiap bulan dengan hasil Reksa Dana dengan risiko tertinggi, terendah, dan rata-rata pada 2015, 2016, dan 2017. Perhitungan standar deviasi dimulai dari Reksa Dana Syariah Saham, setelahnya Reksa Dana Syariah Pendapatan Tetap, Reksa Dana Syariah Campuran, dan Reksa Dana Syariah Pasar Uang.

Hasil perhitungan standar deviasi bulanan untuk Reksa Dana Syariah Saham pada 2015, 2016, 2017, secara lengkap dapat dilihat pada Tabel 5.

\section{Tabel 5}

Hasil Pengukuran Risiko (Standar Deviasi)

Reksa Dana Syariah Saham Bulanan pada 2015-2017

\begin{tabular}{|c|l|l|c|}
\hline Tahun & \multicolumn{1}{|c|}{ Bulan } & \multicolumn{1}{c|}{ Keterangan } & Standar deviasi \\
\hline 2015 & \multirow{2}{*}{$\begin{array}{l}\text { Januari sampai } \\
\text { Desember }\end{array}$} & Tertinggi (Oktober) & 55,61118 \\
\cline { 3 - 4 } & & Terendah (Mei) & 6,663863 \\
\cline { 3 - 4 } & & Rata-Rata & 21,34515 \\
\hline \multirow{2}{*}{2016} & \multirow{2}{*}{$\begin{array}{l}\text { Januari sampai } \\
\text { Desember }\end{array}$} & Tertinggi (Juli) & 42,6144 \\
\cline { 3 - 4 } & & Terendah (Mei) & 3,173813 \\
\cline { 3 - 4 } & Rata-Rata & 17,13257 \\
\hline \multirow{2}{*}{2017} & $\begin{array}{l}\text { Januari sampai } \\
\text { Desember }\end{array}$ & Tertinggi (Januari) & 18,58609 \\
\cline { 3 - 4 } & & Terendah (Febuari) & 2,9499135 \\
\cline { 3 - 4 } & & Rata-Rata & 9,2790993 \\
\hline
\end{tabular}

Sumber: data diolah

Berdasarkan data pada Tabel 5 pada kolom standar deviasi menunjukkan nilai risiko Reksa Dana Saham terbesar pada tahun 2015 bulan Oktober yaitu sebesar 55,61118, sedangkan paling rendah pada tahun 2017 bulan Febuari sebesar 2,9499135. Kesimpulan hasil perhitungan resiko Reksa Dana Saham bahwa resiko paling tinggi pada tahun 2015 dengan nilai rata-rata sebesar 21,34515. Resiko turun pada tahun 2016 sebesar 17,13257 dan hanya sebesar 9,2790993 pada tahun 2017. Resiko mengalami penurunan setiap tahunnya.

Analisis perhitungan risiko, dengan standar deviasi, yang kedua adalah Reksa Dana Pendapatan Tetap. Standar deviasi bulanan pada 2015, 2016 dan 2017 secara lengkap dapat dilihat pada Tabel 6. 
Tabel 6

Hasil Pengukuran Risiko (Standar Deviasi)

Reksa Dana Syariah Pendapatan Tetap Bulanan pada 2015-2017

\begin{tabular}{|c|c|c|c|}
\hline Tahun & Bulan & Keterangan & Standar deviasi \\
\hline \multirow[t]{3}{*}{2015} & \multirow{3}{*}{$\begin{array}{l}\text { Januari sampai } \\
\text { Desember }\end{array}$} & Tertinggi (Januari) & 8,972313 \\
\hline & & Terendah (Mei) & 1,103153 \\
\hline & & Rata-Rata & 3,342146 \\
\hline \multirow[t]{3}{*}{2016} & \multirow[t]{3}{*}{$\begin{array}{l}\text { Januari sampai } \\
\text { Desember }\end{array}$} & Tertinggi (Maret) & 8,163334 \\
\hline & & Terendah (November) & 2,230821 \\
\hline & & Rata-Rata & 3,984344 \\
\hline \multirow[t]{3}{*}{2017} & \multirow{3}{*}{$\begin{array}{l}\text { Januari sampai } \\
\text { Desember }\end{array}$} & Tertinggi(September) & 8,016247 \\
\hline & & Terendah (Desember) & 1,568929 \\
\hline & & Rata-Rata & 3,072486 \\
\hline
\end{tabular}

Sumber: data diolah

Berdasarkan data pada Tabel 6 pada kolom deviasi standar dapat dilihat bahwa risiko Reksa Dana Syariah Pendapatan Tetap terbesar terjadi pada tahun 2015 bulan Januari sebesar 8,972313, terendah bulan Mei 2015 sebesar 1,103153, rata-rata resiko bulan Januari-Desember tahun 2015 sebesar 3,342146. Rata-rata tertinggi ada di tahun 2016 yaitu sebesar 3,984344. Kesimpulan dari hasil perhitungan resiko Reksa Dana Syariah Pendapatan Tetap bahwa resiko tertinggi ada pada tahun 2016.

Analisis perhitungan risiko, dengan standar deviasi yang ketiga adalah Reksa Dana Campuran. Standar deviasi bulanan pada 2015, 2016 dan 2017 secara lengkap dapat dilihat pada Tabel 7.

Tabel 7

Hasil Pengukuran Risiko (Standar Deviasi)

Reksa Dana Syariah Campuran Bulanan pada 2015-2017

\begin{tabular}{|c|l|l|c|}
\hline Tahun & \multicolumn{1}{|c|}{ Bulan } & \multicolumn{1}{|c|}{ Keterangan } & Standar deviasi \\
\hline 2015 & $\begin{array}{l}\text { Januari sampai } \\
\text { Desember }\end{array}$ & $\begin{array}{l}\text { Tertinggi } \\
\text { (Oktober) }\end{array}$ & 42,87239 \\
\cline { 3 - 4 } & $\begin{array}{l}\text { Terendah } \\
\text { (Desember) }\end{array}$ & 3,803252 \\
\cline { 3 - 4 } & Rata-Rata & 15,00697 \\
\hline 2016 & $\begin{array}{l}\text { Januari sampai } \\
\text { Desember }\end{array}$ & Tertinggi (Juli) & 33,31873 \\
\cline { 3 - 4 } & Terendah (Mei) & 4,041393 \\
\cline { 3 - 4 } & $\begin{array}{l}\text { Januari sampai } \\
\text { Desember }\end{array}$ & $\begin{array}{l}\text { Tertinggi } \\
\text { (Januari) }\end{array}$ & 13,74155 \\
\cline { 3 - 4 } & Terendah (Mei) & 13,1748 \\
\cline { 3 - 4 } & & Rata-Rata & 6,1374838 \\
\hline
\end{tabular}

Sumber: data diolah

Berdasarkan Tabel 7 pada kolom deviasi standar menunjukkan nilai risiko Reksa Dana Campuran terbesar pada tahun 2015 bulan Oktober sebesar 42,87239, terendah pada tahun 2017 bulan Mei sebesar 1,414838. Hasil Pengukuran Risiko 
rata-rata Reksa Dana Campuran terbesar pada tahun 2015 yaitu sebesar 15,00697. Rata- rata menurun pada tahun 2016 sebesar 13,74155. Resiko rata-rata Reksa Dana Syariah selalu mengalami penurunan setiap tahunnya pada tahun 2017 sebesar 6,137968. Kesimpulan dari hasil perhitungan resiko Reksa Dana Campuran bahwa resiko tertinggi ada di tahun 2015.

Analisis perhitungan risiko, dengan standar deviasi yang keempat adalah Reksa Dana Syariah Pasar Uang. Standar deviasi bulanan pada 2015, 2016, dan 2017 secara lengkap dapat dilihat pada Tabel 8.

\section{Tabel 8}

Hasil Pengukuran Risiko (Standar Deviasi)

Reksa Dana Syariah Pasar Uang Bulanan pada 2015-2017

\begin{tabular}{|c|l|l|c|}
\hline Tahun & \multicolumn{1}{|c|}{ Bulan } & Keterangan & Standar deviasi \\
\hline 2015 & Januari sampai Desember & Tertinggi (April) & 0,132001245 \\
\cline { 3 - 4 } & & $\begin{array}{l}\text { Terendah } \\
\text { (Januari) }\end{array}$ & 0,001833303 \\
\cline { 3 - 4 } & Rata-Rata & 0,092475074 \\
\hline 2016 & Januari sampai Desember & $\begin{array}{l}\text { Tertinggi } \\
\text { (Januari) }\end{array}$ & 0,12257258 \\
\cline { 3 - 4 } & & $\begin{array}{l}\text { Terendah } \\
\text { (Agustus, } \\
\text { September) }\end{array}$ & 0,02451452 \\
\cline { 3 - 4 } & Rata-Rata & 0,08902227 \\
\hline \multirow{2}{*}{2017} & Januari sampai Desember & Tertinggi (Juli) & 2,696597 \\
\cline { 3 - 4 } & & $\begin{array}{l}\text { Terendah } \\
\text { (November) }\end{array}$ & 2,230821 \\
\cline { 3 - 4 } & & Rata-Rata & 2,441237 \\
\hline
\end{tabular}

Sumber: data diolah

Berdasarkan Tabel 8 pada kolom standar deviasi menunjukkan nilai risiko Reksa Dana Pasar Uang terbesar pada 2017 yaitu bulan Juli sebesar 2,696597, terkecil pada 2015 Januari sebesar 0,001833303. Rata- rata tertinggi ada pada tahun 2017 yaitu sebesar 2,441237, yang menunjukkan resiko terbesar Reksa Dana Syariah Pasar Uang ada di 2017 sebesar 2,441237.

Maka dapat dapat dilihat pada tabel 9. pengukuran tingkat risiko rata - rata bulanan reksa dana syariah tahun 2015- 2017 masing - masing reksa dana sebagai berikut.

Tabel 9

Risiko Rata-rata Bulanan Reksa Dana Syariah pada 2015 - 2017

\begin{tabular}{|c|c|c|c|c|}
\hline Tahun & $\begin{array}{c}\text { Reksa Dana } \\
\text { Syariah Saham }\end{array}$ & $\begin{array}{c}\text { Reksa Dana } \\
\text { Syariah } \\
\text { Pendapatan } \\
\text { Tetap }\end{array}$ & $\begin{array}{c}\text { Reksa Dana } \\
\text { Syariah } \\
\text { Campuran }\end{array}$ & $\begin{array}{c}\text { Reksa Dana } \\
\text { Syariah } \\
\text { Pasar } \\
\text { Uang }\end{array}$ \\
\hline 2015 & 21,34515 & 3,342146 & 15,00697 & 0,092475074 \\
\hline
\end{tabular}




\begin{tabular}{|c|r|r|r|r|}
\hline 2016 & 17,13257 & 3,984344 & 13,74155 & 0,08902227 \\
\hline 2017 & 9,2790993 & 3,072486 & 6,137968 & 2,441237 \\
\hline
\end{tabular}

Sumber: data diolah

Berdasarkan Tabel 9 menunjukkan risiko rata-rata berbagai jenis Reksa Dana Syariah yang memberikan kontribusi terbesar kepada investor yaitu Reksa Dana Syariah Saham sebesar 21,34515 persen pada 2015. Risiko rata-rata terbesar selanjutnya yaitu Reksa Dana Syariah Campuran sebesar 15,00697 pada tahun 2015. Risiko rata-rata berikutnya yaitu Reksa Dana Syariah Pendapatan Tetap tahun 2016 yaitu 3,984344. Risiko terkecil ada di Reksa Dana Pasar Uang pada tahun 2017 sebesar 2,441237. Kesimpulan dari pada tabel 10 yaitu Reksa Dana Syariah yang memberikan risiko rata-rata tertinggi adalah Reksa Dana Syariah Saham.

\section{Pengukuran Kinerja Reksa Dana}

Pengukuran kinerja Reksa Dana pertama, adalah kinerja semua jenis Reksa Dana pada 2015, yaitu Reksa Dana Syariah Saham, Reksa Dana Syariah Pendapatan Tetap, Reksa Dana Syariah Campuran, dan Reksa Dana Syariah Pasar Uang.

Hasil perhitungan Indeks Sharpe dari semua jenis Reksa Dana Syariah tersebut dapat dilihat pada Tabel 10.

\section{Tabel 10}

Hasil Indeks Sharpe Reksa Dana Syariah Pada Tahun 2015

\begin{tabular}{|c|l|c|c|c|c|}
\hline Tahun & \multicolumn{1}{|c|}{ Bulan } & Saham & Campuran & $\begin{array}{c}\text { Pendapatan } \\
\text { Tetap }\end{array}$ & Pasar uang \\
\hline \multirow{3}{*}{2015} & Januari & $-0,6456$ & $-0,46502$ & $-0,659808$ & $-4227,34$ \\
\cline { 2 - 6 } & Febuari & $-0,42793$ & $-0,44071$ & $-2,013004$ & $-63,27$ \\
\cline { 2 - 6 } & Maret & $-0,50557$ & $-0,62142$ & $-5,568514$ & $-54,9582$ \\
\cline { 2 - 6 } & April & $-1,29742$ & $-1,90207$ & $-2,637177$ & $-51,5147$ \\
\cline { 2 - 6 } & Mei & $-0,83358$ & $-1,77384$ & $-6,84855$ & $-131,843$ \\
\cline { 2 - 6 } & Juni & $-0,39468$ & $-0,48115$ & $-4,895059$ & $-63,27$ \\
\cline { 2 - 6 } & Juli & $-0,72028$ & $-1,95936$ & $-1,281191$ & $-62,1078$ \\
\cline { 2 - 6 } & Agustus & $-0,34951$ & $-0,42041$ & $-3,849437$ & $-61,5413$ \\
\cline { 2 - 6 } & September & $-0,92161$ & $-1,401$ & $-4,32456$ & $-56,3596$ \\
\cline { 2 - 6 } & Oktober & 0,069096 & 0,029023 & $-1,34904$ & $-63,27$ \\
\cline { 2 - 6 } & November & $-0,60722$ & $-0,78909$ & $-1,595693$ & $-300,638$ \\
\cline { 2 - 6 } & Desember & $-1,16737$ & $-2,14516$ & $-1,997055$ & $-70,4539$ \\
\hline
\end{tabular}

Sumber: data diolah

Berdasarkan tabel 10 menunjukkan bahwa kinerja Reksa Dana Syariah terbaik pada tahun 2015 adalah Reksa Dana Syariah Saham yang mempunyai nilai indeks Sharpe sebesar 0,069096. Kinerja Reksa Dana Syariah terbaik kedua adalah Reksa Dana Syariah Campuran dengan nilai Sharpe 0,029023. Kinerja selanjutnya yaitu Reksa Dana Syariah Pendapatan Tetap sebesar -0,659808 dan terakhir Reksa Dana Syariah Pasar Uang sebesar -51,5147.

Analisis kinerja Reksa Dana yang kedua, dengan Indeks Sharpe untuk semua jenis Reksa Dana, hasilnya dapat dilihat pada Tabel 11. 
Tabel 11

Hasil Indeks Sharpe Reksa Dana Syariah Pada Tahun 2016

\begin{tabular}{|c|l|c|c|c|c|}
\hline Tahun & \multicolumn{1}{|c|}{ Bulan } & Saham & Campuran & $\begin{array}{c}\text { Pendapatan } \\
\text { Tetap }\end{array}$ & Pasar uang \\
\hline \multirow{3}{*}{2016} & Januari & $-0,85072$ & $-0,68074$ & $-1,34443$ & $-53,8456$ \\
\cline { 2 - 6 } & Febuari & $-0,0632$ & $-0,16293$ & $-1,11192$ & $-58,6985$ \\
\cline { 2 - 6 } & Maret & $-0,03171$ & $-0,1203$ & $-0,62291$ & $-61,6038$ \\
\cline { 2 - 6 } & April & $-0,53828$ & $-1,15982$ & $-1,41573$ & $-54,8569$ \\
\cline { 2 - 6 } & Mei & $-2,18853$ & $-1,63239$ & $-2,78028$ & $-60,3761$ \\
\cline { 2 - 6 } & Juni & $-0,3628$ & $-0,42435$ & $-1,96939$ & $-64,3321$ \\
\cline { 2 - 6 } & Juli & 0,05143 & 0,008875 & $-1,00677$ & $-67,2641$ \\
\cline { 2 - 6 } & Agustus & $-0,17285$ & $-0,18111$ & $-1,82008$ & $-259,846$ \\
\cline { 2 - 6 } & September & $-0,88524$ & $-1,15747$ & $-1,78964$ & $-259,846$ \\
\cline { 2 - 6 } & Oktober & $-1,11373$ & $-1,53169$ & $-2,42128$ & $-65,0427$ \\
\cline { 2 - 6 } & November & $-0,41198$ & $-0,45117$ & $-3,07286$ & $-62,9532$ \\
\cline { 2 - 6 } & Desember & $-0,69286$ & $-0,89394$ & $-1,5637$ & $-59,1258$ \\
\hline
\end{tabular}

Sumber: data diolah

Berdasarkan Tabel 11 menunjukkan bahwa kinerja Reksa Dana syariah terbaik pada 2016 adalah Reksa Dana Syariah Saham yang mempunyai nilai indeks Sharpe sebesar 0,05143. Kinerja Reksa Dana Syariah terbaik kedua adalah Reksa Dana Campuran dengan nilai Sharpe 0,008875. Kinerja selanjutnya yaitu Reksa Dana Syariah Pendapatan Tetap sebesar -0,62291 dan terakhir Reksa Dana Syariah Pasar Uang sebesar -53,8456.

Analisis kinerja Reksa Dana Syariah yang ketiga, dengan Indeks Sharpe untuk semua jenis Reksa Dana, hasilnya dapat dilihat pada Tabel 12.

Tabel 12

Hasil Indeks Sharpe Reksa Dana Syariah Pada Tahun 2017

\begin{tabular}{|l|l|c|c|c|c|}
\hline Tahun & \multicolumn{1}{|c|}{ Bulan } & Saham & Campuran & $\begin{array}{c}\text { Pendapatan } \\
\text { Tetap }\end{array}$ & Pasar uang \\
\hline \multirow{3}{*}{2017} & Januari & $-0,05161$ & $-0,15658$ & $-0,9563$ & $-1,60691$ \\
\cline { 2 - 6 } & Febuari & $-1,56728$ & $-1,36225$ & $-1,87951$ & $-1,65914$ \\
\cline { 2 - 6 } & Maret & $-0,58927$ & $-0,60119$ & $-1,87951$ & $-1,8144$ \\
\cline { 2 - 6 } & April & $-0,08873$ & $-0,27195$ & $-1,6414$ & $-1,75324$ \\
\cline { 2 - 6 } & Mei & $-0,71152$ & $-3,56124$ & $-2,37954$ & $-1,87951$ \\
\cline { 2 - 6 } & Juni & $-0,90655$ & $-0,66549$ & $-2,21807$ & $-1,75324$ \\
\cline { 2 - 6 } & Juli & $-0,67788$ & $-1,15453$ & $-1,29808$ & $-1,55752$ \\
\cline { 2 - 6 } & Agustus & $-0,56228$ & $-0,9159$ & $-1,95562$ & $-1,54427$ \\
\cline { 2 - 6 } & September & $-0,52265$ & $-0,77966$ & $-0,32621$ & $-1,44715$ \\
\cline { 2 - 6 } & Oktober & $-0,27699$ & $-0,39301$ & $-1,36764$ & $-1,68046$ \\
\cline { 2 - 6 } & November & $-0,45138$ & $-1,21755$ & $-0,90029$ & $-1,70117$ \\
\cline { 2 - 6 } & Desember & $-0,65405$ & $-0,72419$ & $-2,50489$ & $-1,64037$ \\
\hline
\end{tabular}

Sumber: data diolah

Berdasarkan Tabel 12 menunjukkan bahwa kinerja Reksa Dana Syariah terbaik pada 2017 adalah Reksa Dana Syariah Saham yang mempunyai nilai indeks Sharpe sebesar -0,05161. Kinerja Reksa Dana Syariah terbaik kedua adalah Reksa Dana Syariah Campuran dengan nilai Sharpe -0,15658. Kinerja 
selanjutnya yaitu Reksa Dana Syariah Pendapatan Tetap sebesar -0,32621 dan terakhir Reksa Dana Syariah Pasar Uang sebesar -1,44715.

Maka dapat dilihat pada tabel 13. Kinerja masing-masing reksadana syariah tahun 2015-2017 sebagai berikut.

Tabel 13

Kinerja Disesuaikan Risiko Reksa Dana Syariah pada 2015-2017

\begin{tabular}{|c|c|c|c|c|}
\hline Tahun & $\begin{array}{c}\text { Reksa Dana } \\
\text { Syariah } \\
\text { Saham }\end{array}$ & $\begin{array}{c}\text { Reksa Dana } \\
\text { Pendapatan } \\
\text { Tetap }\end{array}$ & $\begin{array}{c}\text { Reksa Dana } \\
\text { Campuran }\end{array}$ & $\begin{array}{c}\text { Reksa Dana } \\
\text { Pasar Uang }\end{array}$ \\
\hline 2015 & $-0,65014$ & $-3,084924$ & $-1,03085$ & $-433,881$ \\
\hline 2016 & $-0,60504$ & $-1,74325$ & $-0,62321$ & $-93,9826$ \\
\hline 2017 & $-0,58835$ & $-1,60892$ & $-0,98363$ & $-1,66978$ \\
\hline
\end{tabular}

Sumber: data diolah

Berdasarkan Tabel 13 menunjukkan kinerja berbagai jenis Reksa Dana Syariah yang terbaik yaitu Reksa Dana Syariah Saham dengan nilai indeks Sharpe sebesar -0,58835 persen pada 2017. Kinerja terbaik selanjutnya yaitu Reksa Dana Syariah Campuran pada 2016 yaitu nilai Sharpe sebesar -0,62321 persen. Ketiga ada Reksa Dana Syariah Pendapatan Tetap nilai Sharpe sebesar -1,60892 persen pada tahun 2017 dan terakhir adalah Reksa Dana Syariah pasar uang nilai Sharpe sebesar -1,66978 persen. Kesimpulan dari pada Tabel 13 yaitu kinerja Reksa Dana Syariah yang terbaik adalah Reksa Dana Syariah Saham.

\section{KESIMPULAN}

Hasil penelitian menunjukkan bahwa kinerja Reksa Dana Syariah yang terbaik adalah Reksa Dana Syariah Saham. Reksa Dana Syariah Saham terbaik berdasarkan pengukuran kinerja dengan menggunakan metode sharpe dimana ada tiga indikator pengukuran kinerja, yaitu tingkat pengembalian yang dihitung secara bulanan dan rata-rata tahunan, tingkat risiko yang diukur menggunakan standar deviasi, kemudian diakhiri dengan metode sharpe.

Dari ketiga analisa tersebut menunjukkan Reksa Dana saham memperoleh tingkat pengembalian dengan hasil tertinggi dibandingkan ketiga jenis Reksa Dana Syariah lainnya. Tingkat resiko yang dihitung menggunakan standar deviasi, dimana Reksa Dana Syariah Saham memiliki resiko yang tertinggi dibandingkan Reksa Dana Syariah lainnya secara bulanan dan rata-rata tahunan. Selanjutnya analisa dengan indeks sharpe dimana nilai Reksa Dana Syariah Saham lebih tinggi dibandingkan jenis Reksa Dana Syariah lainnya. Indeks sharpe yang semakin tinggi menunjukkan kinerja yang semakin baik.

\section{DAFTAR PUSTAKA}

Dewan Syariah Nasional,. 2003. Himpunan Fatwa Dewan Syariah Nasional. Bank Indonesia- Dewan Syariah Nasional. Edisi 2. Jakarta.

Fatra,O.S. 2014. Analisis Perbandingan Kinerja Reksadana Konvensional dengan Reksadana Syariah di Indonesia. Skripsi, Jember: FE UNEJ. 
Hakim, S. \& Rashidian, M. 2002. Risk and Return of Islamic Stock Market. Presentation to Economic Research Forum Annual Meetings Shariah. UEA.

Haruman, T. \& Hasbi, H. 2005. Evaluasi Kinerja dan Prospek Reksadana Syariah dalam Pasar Modal di Indonesia. Usahawan, Vol. XXXIV No.01 (Januari 2005), 40-49.

Hasbi, H. 2010. Kinerja Reksadana Syariah Tahun 2009 di Indonesia. Vol.14 No.01 (Januari 2010), 62-73.

Dow Jones Islamic Indices. The Journal of Investing, Vol.14, 105-124. Indriantoro,

Nur \& Bambang Supomo. 2016. Metodelogi Penelitian Bisnis untuk Akuntasi dan Manajemen. Edisi Ke-1. Yogyakarta: BPFE.

Jogianto (2009). Analisis Investasi dan Portofoli. BPFE. Yogyakarta.

Praska Putrantyo. 2013. Menakar Prospek Reksa Dana 2013. www.infovesta. com/researchanalyst

Raudhah TW, Ahmad Juanda \& Dhaniel Syam. 2018. Analisa Kinerja Reksadana Syariah di Pasar Modal Indonesia Menggunakan Metode Sharpe. Jurnal Akademi Akuntansi 2018 Volume.1 No.1

Suryantini, N. P. S. 2007. Perbedaan Kinerja Portofolio berdasarkan Strategi Portofolio Aktif dan Pasif pada Saham LQ 45 di BEI. Buletin Studi Ekonomi, Vol.12 No 3, 299-313.

Sutedi, Adrian. 2011. Pasar Modal Syariah Sarana Investasi Keuangan Berdasarkan Prinsip Syariah. Jakarta: Sinar Grafika

Tanderlilin, Eduardus. 2010. Portofolio dan Investasi. Yogyakarta: Kanisius.

Werner R Murhadi. 2009. Penilaian Kinerja Reksadana. Pada www. wernermurhadi.files.wordpress.com, diunduh tanggal 11 nopember 2013.

Wiksuana, I.GB. \& Purnawati, N.K.2008, Konsistensi Risk-Adjusted Performance sebagai Pengukur Kinerja Portofolio Saham di Pasar Modal Indonesia. Buletin Studi Ekonomi, Vol.13 No.2, 174-183.

www.bareksa.com www.bi.go.id www.ojk.go.id 